\title{
Effects of the Banking (Amendment) Act of 2016 on the Kenyan Banking Sector
}

\section{Nicholas Karani Njebi*}

Equity Bank Kenya Limited, Meru County, Kenya

\begin{abstract}
The Banking (Amendment) Act of 2016 enacted by the Kenyan Parliament was envisioned with the intentions of stabilizing lending and deposit taking transactions by financial service providers such as banks. However, the emerging reality is of a banking industry living through the significant effects of this Banking (Amendment) Act of 2016. The effects have resulted in opposing conversations with those in support of continued implementation of the Act and those calling for its repeal. Some of these effects are positive such as protecting customers from exploitation by greedy financial institutions. Other effects are negative such as declining capacity for banks to give loans and decrease in the ability of customers to borrow. In the face of these effects the banking sector has realized the unsustainability of the Act. The sector is calling for its repeal with several suggested ways forward such as diversifying funding sources for various economic activities. However, whether one is in support of the Act or calling for its repeal, the reality is that the Kenyan banking space has undergone a serious disruption. This calls for sustainable ways forward in regulation, customer protection and cultivating growth of the banking industry.
\end{abstract}

Keywords: The Banking (Amendment) Act of 2016; Effects; Repeal; Ways forward

\section{Effects of the Banking (Amendment) Act of 2016 on the Kenyan Banking Sector}

A Discussion on the Effects of Enforcing the Banking (Amendment) Act, 2016 in Kenya and the way Forward if it were to be Repealed - The Republic of Kenya, 2016 [1] published in the Kenya Gazette the Banking (Amendment) Act No. 25 of 2016 that was enacted by the Parliament of Kenya as an amendment to the Banking Act. It was assented on 24th August, 2016. It commenced operation on 14th September, 2016. The main areas the Kenyan Parliament sought to amend are described as follows. A bank or financial institution shall, before granting a loan to a borrower, disclose all the charges and terms relating to the loan. A bank or a financial institution shall set the maximum interest rate chargeable for a credit facility in Kenya at no more than four per cent, the base rate set and published by the Central Bank of Kenya; and the minimum interest rate granted on a deposit held in interest earning in Kenya to at least seventy per cent, the base rate set and published by the Central Bank of Kenya. A person shall not enter into an agreement or arrangement to borrow or lend directly or indirectly at an interest rate in excess of that prescribed by law.

A bank or financial institution which contravenes the amendments provided in this Kenya Banking (Amendment) Act, 2016 commits an offence and shall, on conviction, be liable to a fine of not less than one million shillings, or in default, the Chief Executive Officer of the bank or financial institution shall be liable to imprisonment for a term not less than one year according to the Banking Act published by the Republic of Kenya, 2016 [1]. The Act of revolutionizing the way Kenyan Banks conduct lending and deposit taking transactions has resulted in various conversations in support of enforcing the Act and others calling for its repeal. The following discussion will shed light on the effects of enforcing the Act. The discussion will also provide the way forward if the Act were to be repealed.

One of the effects of enforcing this Act is to protect ordinary Kenyans from exploitation when they are conducting monetary transactions in banking institutions. The reality before the enactment of the amended Banking Act 2016 was that Kenyans were consuming costly loan products. This reality was corroborated in a report by Ngugi [2] derived from information on the overall average weighted lending rate for each commercial bank published on the CBK website. It described the weighted average rate charged by commercial banks before enactment of the Banking Act 2016 across all loan categories. These loan categories are corporate, business, personal, and overdrafts. The report further showed that the most expensive lender then was lending at a rate of $24.6 \%$ while the cheapest was lending at $14.7 \%$. These lending costs prohibited potential borrowers from applying for loans due to the real fear of inability to pay back the loan. The effect of the amended Banking Act 2016 was to protect customers from these exploitative lending rates.

Another effect was to promote conditions for fair competition among lenders when pricing credit facilities. This is because as per the Act, all banks were required by law to use the Central Bank of Kenya Reference Rate (the CBRR) as the benchmark upon which to price their loans. Further disclosures are required by the CBK on interest rates levied by banks on an aggregate monthly basis according to Kamami and Michira [3]. This effect of fair competition comes in because with the enforced disclosures to both the customer and the regulators, an environment of fairness is gradually cultivated. Undue advantage due to unfair competitive practices will be eliminated and financial institutions will compete fairly. Customers will also be free to visit whichever lending institution they desire.

Another effect is to promote transparency by revealing information on the cost of credit to borrowers. However, it was not the general conduct of business before in the banking industry. Customers used

*Corresponding author: Nicholas Karani Njebi, MBA, Equity Bank Kenya Limited, Meru County, Kenya, Tel: +254724467007; E-mail: karaninicholas3@gmail.com

Received December 02, 2017; Accepted December 29, 2017; Published January 09,2018

Citation: Njebi NK (2018) Effects of the Banking (Amendment) Act of 2016 on the Kenyan Banking Sector. J Bus Fin Aff 7: 310. doi: 10.4172/2167-0234.1000310

Copyright: (c) 2018 Njebi NK. This is an open-access article distributed under the terms of the Creative Commons Attribution License, which permits unrestricted use, distribution, and reproduction in any medium, provided the original author and source are credited. 
to be given the letter of offer only. Transaction costs were a mystery closely guarded by the lender. Customers had no real record of the lifecycle of their loan and the total costs of borrowing before entering into contract to borrow. One of the effects of the Banking Act 2016 by the Republic of Kenya, 2016 [1] was to ensure by law that financial institutions disclose all the charges and terms relating to the loan before advancing the credit facility. Thus, unlike before, banks currently give customers the repayment schedule and the breakdown of the total cost of credit in addition to the letter of offer. This allows customers to make informed decisions on whether or not to borrow.

Enforcement of this Act will also have an effect of biasness in the industry. This is because the amendment has been made specifically to the Banking Act. Kamami and Michira [3] argue that its application excludes microfinance institutions, savings and credit organisations, and mobile money service providers, among others, from its application. The effect of biasness comes in because all these financial service providers are serving in the same industry. They are chasing the same customers. However, because of the amended Banking Act, the Banks face stricter regulation than their competitors. It amounts to subjective application of regulatory laws for the same industry players.

Another effect is to clean the public image of the banking industry by getting rid of the cartel tag attributed to the sector. The cartel accusation was in relation to the high transaction levies and interest costs charged by banks before the Banking Amendment Act of 2016. It was also in light of accusations by regulatory institutions such as the Central Bank of Kenya (CBK) and the Competition Authority of Kenya (CAK) that the big banks are colluding in a cartel like behaviour to manipulate the industry. This cartel behaviour was captured in a report by Ngugi [2] which showed that the Kenyan banking sector could be promoting collusion to stifle healthy competition hence the high cost of credit and astronomical transaction fees that banks charged customers. The report also quoted the CBK Governor Dr. Njoroge reprimanding the large lenders for taking advantage of their dominance to increase costs. The direct effect of the Banking Act of 2016 was to contribute in cleaning this negative image that had been attributed to the industry.

Another effect was limited access to credit for unsecured loans, the informal sector and SMEs. This is the reality as reported by Cytonn Investment, 2017 [4] where they observed that lending has declined in commercial banks in Kenya. It declined from a high of $15.7 \%$ in the pre-interest capping period to a low of $7.1 \%$ after interest capping. The report by Cytonn Investment, 2017 [5] further noted a decline in private sector credit growth from a high of $25.8 \%$ in June 2014 to $2.1 \%$ recorded in May 2017. These declines in both capacity to lend by banks and the ability to take up loans by borrowers led to shrinking access to core banking services. Most borrowers used to access credit before the interest capping regime. Especially the risky category of borrowers with inadequate collateral. Banks also used to fund unsecured loans. However, banks are currently shying away from lending that will increase exposure to unmitigated risks.

The Banking Act 2016 has also had the effect of job insecurity in the banking sector. There has been significant retrenchment of staff working in the Banking industry since the Act was enacted. The Business Daily, 2016 [6] agreed with this effect when they reported that interest capping triggered a series of retrenchments in Kenya's banking sector where 1,000 bankers lost their jobs in just three months. This is a very insecure work environment. However, there are voices urging a repeal of the Act. These voices are pointing out that the effects of the Act are not supportive of a sustainable banking regime. They also suggest various ways forward as discussed below.
A review of price risks for loan products will have to be done as one of the ways forward. When the Act is amended, lenders will have to review how they price risks by looking at individual borrowers and the projects to be funded according to the Business Daily, 2017 [7]. A new approach is welcome that is tailored to the varying circumstances of every customer instead of applying a rigid system for pricing risk that ends up punishing borrowers.

Another area of improvement is using credit history as a tool for gauging credit worthiness. Credit Reference Bureaus [CRB] need to be restructured and strengthened to act as sources of information for lenders on which customer bears lower credit risk. Development of this tool will create a future where borrowers can get better rates based on their credit history according to a report by the Business Daily, 2017 [7]. Currently, borrowers regard CRB reports as red cards for borrowers. They are viewed with suspicion by borrowers because they are used by banks as a reason to deny customers credit. Nowadays, the first test of a borrower is whether they are adversely listed by CRB. If so, no further credit discussions are encouraged.

Going forward, market discipline by financial institutions will be enhanced according to Business Daily, 2017. This will ensure that commercial banks will have to be more disciplined in the pricing of loans so as not to overcharge borrowers. Also going forward, borrowers need consumer education. This education will cover access to credit, the use of collateral and establishing a strong credit history by the consumer according to Cytonn Investment, 2017 [4]. Financial education leads to a more empowered customer in decision making. It also improves borrower behaviour.

Going forward, funding sources need to be diversified according to Cytonn Investment, 2017 [5]. This will enable borrowers to tap into alternative avenues of funding that are more flexible and pocketfriendly. In the Kenyan market, bank funding accounts for over $95.0 \%$ of funding sources. Other sources of funding such as capital markets based funding need to be explored. It will reduce the burden on banks to fund enterprises alone. It also encourages competition among various funding alternatives available.

Going forwards, there is also a need for increased transparency. Transparent institutions self-regulate. They also avoid unfair competition practices and customer exploitation. Steps have already been made to actualise this through recent initiatives by the CBK and Kenya Bankers Association (KBA) to enact regulations and set up the cost of credit website according to Cytonn Investment, 2017 [5]. Also the enactment of Movable Property Security Rights Bill 2017 will allow borrowers to use a single asset to access credit from different lenders.

In conclusion the Banking Act 2016 has had positive and negative effects in the banking industry. To some industry players, the Act is welcome but to others it requires immediate repeal. Whichever way one chooses, the banking industry has undergone a disruption that invites an urgent rethink on the way it conducts business going forward. A level playing field for banks, a just regulatory regime and fair prices for customers is what is required going forwards.

\section{References}

1. The Republic of Kenya (2016) The Banking (Amendment) Act 2016. Nairobi: Kenya. The Government Printer.

2. Ngugi B (2016) Cartel-Like Behaviour Blamed for High Banking Charges Nairobi, Kenya: Nation Media Group.

3. Kamami C, Michira M (2017) Salient Features of Kenya's Banking Amendment Act, 2016. Law Business Research, London, UK. 
Citation: Njebi NK (2018) Effects of the Banking (Amendment) Act of 2016 on the Kenyan Banking Sector. J Bus Fin Aff 7: 310. doi: 10.4172/21670234.1000310

Page 3 of 3

4. Cytonn Investments (2017) State of Interest Rate Caps.

5. Cytonn Investments (2017) Update on Effect of Interest Rate Cap on Credit Growth \& Cost.
6. Business Daily (2016) Anxiety for Kenya Bank Workers as 1,000 Lose Jobs in Three Months.

7. Business Daily (2017) Kenya's Central Bank Sets Stage for Repeal of Interest Rate Caps. 